\title{
Partisipasi Masyarakat Menanggulangi Lingkungan Demam Berdarah Dengue di Kecamatan Rappocini Kota Makasar
}

\author{
Sri Syatriani* Esse Puji** Andi Susilowati****
}

\begin{abstract}
Abstrak
Demam Berdarah Dengue (DBD) menjadi wabah nasional pada tahun 2006, termasuk Makassar dan beberapa kabupaten di Sulawesi Selatan. Jumlah kasus DBD di kecamatan Rappocini tahun 2006 adalah 160 kasus tanpa kematian. Penelitian bertujuan untuk mengetahui berbagai bentuk partisipasi masyarakat untuk menciptakan lingkungan sehat dalam upaya penanggulangan DBD. Penelitian dilaksanakan di kecamatan Rappocini yang merupakan daerah endemis DBD. Jenis penelitian adalah penelitian observasional dengan pendekatan deskriptif. Sampel adalah kepala keluarga yang ada di Kelurahan Bonto Makkio dan Kelurahan Gunung Sari sebesar 300 KK. Analisis data yang digunakan adalah analisis deskriptif dari setiap variabel. Hasil penelitian menunjukkan bahwa partisipasi masyarakat terhadap upaya penanggulangan DBD rendah sebesar 68\%. Bentuk partisipasi berupa kebiasaan membersihkan lingkungan, kebiasaan menguras tempat penampungan air, kebiasaan menutup tempat penampungan air, dan kebiasaan menggantung pakaian. Berdasarkan hasil penelitian maka direkomendasikan kebijakan penanggulangan DBD perlu mendapat payung hukum berupa peraturan daerah yang memberikan denda administrasi bagi masyarakat serta membentuk kader pemantau jentik yang berbasis keluarga yang diperankan oleh ibu rumah tangga.
\end{abstract}

Kata kunci : Partisipasi masyarakat, DBD, pemantau jentik

\section{Abstract}

Dengue haemorrhagic fever (DHF) has become a national epidemic in 2006, including Makassar and several municipalities in South Sulawesi. DHF patients in 2006 counted 877 patients and 17 people were death (CFR=1.93\%). The Prevalence of DHF in Rappocini district at the same year was 160 cases with no mortality case or CFR=0. The objective of this study is to know the forms of community participation in creating healthy environment to combat DHF. This study is conducted in Rappocini district which is a DHF endemic area. This study is observational and descriptive. Sample is family head of population in subdistrict of Bonto Makkio and sub-district of Gunung Sari which counted 300 family head. Sample is withdrawn by purposive sampling. Data is analyzed by descriptive analysis from each variable. The result of the study indicates that the community participation is still low towards the effort of combating DHF (68\%). The types of participation include habit to clean environment, habit to drain water container, habit to cover water container, and habit to hang the clothes. This study recommends policy to combat DHF which provide administrative penalty and also forming family-based larva controller group which empowers housewives.

Key words : Community participation, DHF, larva controller 
Dengue Haemorhagic Fever atau Demam Berdarah Dengue (DBD) adalah penyakit menular yang disebabkan virus dengue dan ditularkan melalui gigitan nyamuk Aedes aegypti atau Aedes albopictus. Sampai kini, DBD masih menjadi masalah kesehatan masyarakat yang penting karena tingkat keganasan, jumlah kasus dan tingkat endemisitas yang tinggi. Selain itu, penyebaran penyakit sulit dikendalikan serta obat dan vaksin efektif yang belum tersedia. Sekitar 2,5-3,0 milyar yang bermukim di daerah tropis dan subtropis berisiko tinggi penyakit DBD. Setiap tahun, sekitar 102 negara di dunia meliputi Asia (42) Afrika (20) dan Wilayah Pasifik Barat (29) melaporkan 250.000-500.000 kasus DBD. Pada periode 50 tahun terakhir, insiden DBD meningkat 30 kali lebih besar dari periode sebelumnya. ${ }^{1}$ Di negara Asia, DBD termasuk 10 penyebab utama kesakitan dan kematian. Negara dengan tingkat endemisitas kategori A, DBD di Asia Tenggara meliputi Indonesia, Myanmar, dan Thailand. Pada tahun 2003, frekuensi DBD tertinggi di Asia Tenggara adalah Thailand yang melaporkan 62.767 kasus. Pada tahun 2006, 10 dari 11 negara Asia tenggara melaporkan kasus DBD dan Indonesia menggeser posisi Thailand menempati urutan tertinggi.

Di Indonesia, pada periode 1968 - 2007, jumlah kasus dan kematian pada tiap KLB DBD mengalami peningkatan yang sangat progresif. Pada KLB pertama di Surabaya, 1968 jumlah kasus dan kematian dilaporkan paling rendah (58 dan 24). Namun, pada tahun 2002, jumlah kesakitan dan kematian tersebut meningkat 12.867 dan 60 kali lipat (972.133 dan 1.414). ${ }^{2}$ Angka insiden dan angka fatalitas DBD pada setiap KLB bervariasi, tertinggi pada tahun 1998 (35,2 per 100.000 penduduk dan $2 \%$ ), tahun 2006, (114.656; 1.196 dan $1,04 \%)$; penghujung tahun 2007, (124.815; 1.277 dan $1,02 \%) .^{2}$ Semula, penderita terbatas pada kelompok umur $<14$ tahun, kini merambah luas pada semua kelompok umur dari bayi sampai usia lanjut. KLB yang semula terbatas pada pola siklus 5 tahunan kini terjadi setiap waktu. Kematian tertinggi justru terjadi pada masyarakat miskin akibat perilaku yang tidak mendukung kesehatan dan akses pada pelayanan kesehatan yang rendah. Kini, penyakit DBD telah tersebar luas di seluruh provinsi di Indonesia yang mencakup 326 kabupaten/kota. ${ }^{2}$

Pada tahun 2006, Demam Berdarah Dengue yang telah menjadi wabah nasional, juga melanda Kota Makassar dan kabupaten lain di Sulawesi Selatan. Sebelumnya, DBD sudah menjadi masalah kesehatan dengan insiden yang meningkat setiap tahun dan risiko kematian yang tinggi. Jumlah penderita dan fatalitas DBD di Kota Makassar cenderung meningkat, pada tahun 2004 (584 dan 2,05\%), tahun 2005 (832 dan 2,64\%), tahun 2006 (877 dan 1,93\%). ${ }^{3}$ Prevalensi DBD tertinggi dilaporkan di Kecamatan Rappocini dengan jumlah kasus dan fatalitas tahun 2005 (195 kasus dan 2,56), tahun 2006 menurun menjadi 160 dan $\mathrm{CFR}=0 \% .{ }^{4}$

\section{Metode}

Penelitian dengan desain diskriptif cross sectional ini bertujuan untuk mengetahui partisipasi masyarakat menciptakan lingkungan sehat untuk penanggulangan Demam Berdarah Dengue di Kota Makassar. Penelitian dilaksanakan pada bulan Agustus - September 2007. Populasi adalah semua kepala keluarga yang ada di Kelurahan Bonto Makkio dan Kelurahan Gunung Sari Kecamatan Rappocini. Sampel adalah kepala keluarga yang ada di Kelurahan Bonto Makkio dan Kelurahan Gunung Sari. Jumlah sampel di tiap kelurahan meliputi Kelurahan Bonto Makkio (100) dan Kelurahan Gunung (200). Penarikan sampel dilakukan dengan metode purposive sampling dengan kriteria bersedia menjadi responden dan berada wilayah kumuh dan wilayah tidak kumuh. Sumber data yang digunakan adalah sumber data primer yang diperoleh dari hasil wawancara responden dengan menggunakan kuesioner, dan observasi lingkungan perumahan dan pemeriksaan jentik menggunakan instrumen lembar observasi. Data yang telah dikumpulkan diolah dengan menggunakan program Statitiscal Package for Services Solution (SPSS). Analisis data dilakukan dengan analisis deskriptif dari setiap variabel penelitian dan pengukuran House Index (HI), Container Index (CI), dan Breteau Index (BI).

\section{Hasil}

Secara keseluruhan, prevalensi penyakit demam berdarah yang ditemukan di wilayah Kelurahan Bonto Makkio dan Kelurahan Gunung Sari Kecamatan Rappocini pada penelitian ini adalah 9\%. Juga ditemukan sekitar 34\% rumah termasuk dalam kondisi yang kumuh dengan keberadaan jentik di dalam dan sekitar rumah adalah 14\% (Lihat Tabel 1).

\section{Keberadaan Jentik}

Secara keseluruhan wadah yang ditemukan mengandung jentik Aedes aegypti adalah 8,9\%. Distribusi berdasarkan jenis wadah berjentik ditemukan yang terbanyak adalah ban (100\%), diikuti oleh drum $(33,33 \%)$, kolam $(33,33 \%)$, pot bunga $(23,07 \%)$, jerigen $(14,05 \%)$ gentong $(8,33 \%)$, ember $(6,39 \%)$ dan baskom $(4,80 \%)$. Sedangkan yang tidak ada jentik $(0 \%)$ meliputi pot bunga, sumur gali, dispenser, kaleng, kontainer, kulkas, tempayan (Lihat Tabel 2).

Selanjutnya, distribusi jenis bahan wadah yang berjentik Aedes aegypti ditemukan yang terbanyak adalah bahan karet dan seng masing masing $50 \%$, diikuti tanah liat $(16,36 \%)$, semen $(12,00 \%)$, keramik $(10,97 \%)$ plastik $(7,44 \%)$ dan yang terkecil adalah besi, fiber dan kaca masing-masing 0,0\% (Lihat Tabel 3). 
Tabel 1. Karakteristik Responden $(n=300)$

\begin{tabular}{llll}
\hline Karakteristik Variabel & Katagori & f & $\%$ \\
\hline Kejadian DBD & Ada Kasus DBD & 28 & 9,3 \\
Kondisi Rumah & Kumuh & 102 & 33,4 \\
Keberadaan Jentik & Berjentik & 41 & 13,6 \\
\hline
\end{tabular}

Tabel 2. Distribusi Wadah Berjentik Aedes aegypti

\begin{tabular}{llll}
\hline Wadah & Berjentik & Total & Prevalensi \\
\hline Bak & 20 & 193 & 10,36 \\
Ban & 1 & 1 & 100,00 \\
Baskom & 2 & 41 & 4,80 \\
Drum & 1 & 3 & 33,33 \\
Ember & 22 & 344 & 6,39 \\
Gentong & 15 & 114 & 8,33 \\
Jerigen & 17 & 121 & 14,05 \\
Kolam & 1 & 3 & 33,3 \\
Pot Bunga & 3 & 13 & 23,07 \\
Sumur Gali & 0 & 1 & 0.0 \\
Dispenser & 0 & 3 & 0.0 \\
Kaleng & 0 & 1 & 0.0 \\
Kontainer & 0 & 4 & 0.0 \\
Kulkas & 0 & 4 & 0.0 \\
Tempayan & 0 & 77 & 0,0 \\
\hline Total & 82 & 923 & 8,9 \\
\hline
\end{tabular}

Tabel 3. Distribusi Jenis Bahan Wadah Menurut Keberadaan Jentik

\begin{tabular}{llll}
\hline Bahan Wadah & Berjentik & Total & $\%$ \\
\hline Karet & 1 & 2 & 50,00 \\
Seng & 1 & 2 & 50,00 \\
Tanah Liat & 9 & 55 & 16,36 \\
Semen & 12 & 100 & 12,00 \\
Keramik & 9 & 82 & 10,97 \\
Plastik & 50 & 672 & 7,44 \\
Besi & 0 & 4 & 0,00 \\
Fiber & 0 & 4 & 0,00 \\
Kaca & 0 & 2 & 0,00 \\
\hline Jumlah & 82 & 923 & 8,88 \\
\hline
\end{tabular}

\section{Partisipasi Masyarakat}

Partisipasi masyarakat terhadap penanggulangan DBD dilihat dari kebiasaan membersihkan lingkungan dan kebiasaan menguras dan menutup tempat penampungan air. Penelitian ini menemukan secara umum partisipasi masyarakat rendah $(68 \%)$ responden yang membersihkan lingkungan setiap hari $(64 \%)$, menguras tempat penampungan air sebesar 164 (55\%), menutup tempat penampungan air $(60 \%)$ dan yang mempunyai kebiasaan menggantung pakaian sebesar (69\%) (Lihat Tabel 4).

\section{Kepadatan Jentik}

Penelitian ini menemukan nilai density figure House
Indeks (3), Container Indeks (3) dan density figure (4) yang tidak berpotensi untuk terjadi penularan penyakit Demam Berdarah Dengue (Lihat Tabel 5).

\section{Pembahasan}

Di Indonesia, penyakit Demam Berdarah Dengue (DBD) masih memperlihatkan kecenderungan yang semakin meningkat dan penyebaran yang semakin meluas. Sejak KLB pertama di Surabaya pada tahun 1964 sampai sekarang frekuensi kejadian penyakit BDB meningkat ribuan kali lipat dan daerah endemis mencakup hampir seluruh provinsi di Indonesia. Penyebaran tersebut sesuai dengan peningkatan mobilitas dan kepadatan penduduk yang berdampak pada lingkungan pemukiman yang tidak sehat yang merupakan lingkungan ideal bagi perkembangbiakan nyamuk Aedes agypti vektor penyakit BDB.

Pemutusan mata rantai penularan penyakit DBD dapat dilakukan berbagai upaya yang meliputi melenyapkan virus, mengisolasi penderita, menghindari gigitan nyamuk. Pemilihan lokasi penelitian Kelurahan Bonto Makkio dan Kelurahan Gunung Sari, Kecamatan Rappocini, Kota Makassar dilakukan dengan mempertimbangkan tingkat kekumuhan kondisi pemukiman. Daerah kumuh ditentukan berdasarkan pada sarana dan prasarana air bersih, tingkat kepadatan penduduk, kondisi rumah semi permanen yang kumuh juga mencakup lokasi pemukiman warga dalam tatanan ruang yang tidak teratur, pembiayaan yang terbatas. Dalam keadaan yang demikian pengelolaan sampah dilakukan oleh masyarakat sendiri dengan cara tradisional. 4

\section{Jenis Tempat Penampungan Air}

Menurut Departemen Kesehatan Republik Indonesia (1995) nyamuk Aedes aegypti merupakan vektor penyakit DBD. Vektor tersebut berkembang biak dengan mudah apabila di lingkungan tersebut terdapat tempattempat penampungan air bersih, baik bersifat sementara atau yang bersifat permanen seperti bak mandi, drum, gentong, dan pot serta berbagai tempat genangan air yang tidak kontak secara langsung dengan tanah. Air bersih di rumah umumnya menggunakan bak dan ember plastik yang harus ditutup rapat dan paling sedikit dua kali seminggu harus dibersihkan atau dikuras. Bak dan ember plastik seharusnya diletakkan di tempat yang tidak mudah dicemari, lebih tinggi dari lantai, jauh dari tempat sampah dan selalu tertutup rapat. Wadah air yang tidak secara rutin dibersihkan merupakan tempat yang potensial bagi perkembangbiakan jentik Ae. aegypti. Wadah selalu dibersihkan dengan baik dengan jarak waktu dua kali seminggu, dapat memutuskan siklus hidup nyamuk Ae.aegypti dan dapat menurunkan kepadatan Aedes aegypti.

Studi jentik di sembilan kota, menemukan bahwa kontainer yang disukai oleh jentik berturut-turut adalah 
Tabel 4. Partisipasi dan Kebiasaan Membersihkan Lingkungan $(n=300)$

\begin{tabular}{llcl}
\hline Kebiasaan & Katagori & f & $\%$ \\
\hline Partisipasi & Tinggi & 95 & 32 \\
& Rendah & 205 & 68 \\
Membersihkan Lingkungan & Setiap Hari & 192 & 64 \\
& Tidak Setiap Hari & 108 & 36 \\
Frekuensi Menguras & $\leq 1$ minggu & 192 & 64 \\
Menutup Penampungan Air & Tidminggu Ditutup & 108 & 36 \\
& Tertutup \& Terbuka & 105 & 35 \\
Menggantung Pakaian & Ya & 206 & 65 \\
& Tidak & 94 & 31 \\
\hline
\end{tabular}

Tabel 5. Kepadatan Jentik Aedes aegypti

\begin{tabular}{cccc}
\hline Density Figure & House Indeks & Container Indeks & Breteau Indeks \\
\hline 3 & 13,7 & 8,9 & 27,3 \\
\hline
\end{tabular}

tangki reservoir $(53,8 \%)$, drum $(36,5 \%)$, tempayan $(31,5 \%)$ dan bak mandi $(20,5 \%)$. Wadah yang bukan tempat penampungan air meliputi barang bekas $(27,5 \%)$, celah pohon/lubang pagar $(18,7 \%)$ dan tempat minum burung $(9,0 \%) .{ }^{5}$ Pada waktu kejadian wabah DBD di Bantul tahun 1976/1977, dilaporkan bahwa Aedes aegypti lebih sering ditemukan di bak yang terbuat dari semen.

Penelitian ini menemukan dari 300 rumah yang diamati terdapat 41 rumah (14\%) yang positif ditemukan jentik Ae. Aegypti. Selanjutnya, dari 923 tempat penampungan air yang diperiksa, ditemukan positif ada jentik Ae. aegypti (9\%). Berdasarkan jenis wadah yang positif mengadung jentik Ae.aegypti yang paling banyak adalah ember plastik (27\%). Penelitian sebelumnya menunjukkan bahwa persentase wadah positif jentik dalam rumah yang paling banyak adalah bak (75\%) dan di luar rumah adalah ban bekas $(100 \%) .{ }^{6}$ Temuan penelitian ini tampaknya konsisten dengan temuan sebelumnya.

\section{Partisipasi Masyarakat}

Penanggulangan penyakit DBD memerlukan partisipasi aktif masyarakat secara berkesinambungan. Mengingat DBD adalah penyakit yang berbasis lingkungan yang dapat menular dari sumber penularan orang yang terinfeksi virus dengue ke orang yang sehat melalui perantaraan nyamuk Ae. aegypti sebagai vektor. Lingkungan rumah yang bebas dari tempat perindungan nyamuk Ae.aegypti, secara potensial tetap berisiko tinggi untuk terjadi penularan, apabila lingkungan sekitar tidak bersih. Partisipasi masyarakat tersebut dapat berupa kebiasaan membersihkan lingkungan berupa gerakan $3 \mathrm{M}$ yang meliputi kebiasaan menimbun, menguras dan menutup tempat penampungan air serta kebiasaan tidak menggantung pakaian. Kebiasaan membersihkan lingkungan seperti kaleng bekas dapat mengurangi tempat perindukan nyamuk Aedes aegypti yang pada akhirnya akan mengurangi kejadian Demam Berdarah Dengue. Gerakan 3M merupakan cara yang terbaik untuk memberantas jentik Ae.aegypti karena dapat menghilangkan tempat perindukan nyamuk Ae.aegypti. Kebiasaan menggantung pakaian di dalam rumah yang disenangi oleh nyamuk Aedes aegypti untuk tempat beristirahat juga merupakan faktor risiko kuat kejadian DBD. ${ }^{7}$

Penelitian ini menemukan bahwa sebagian besar responden $(68 \%)$ memperlihatkan tingkat partisipasi yang rendah. Masyarakat sebagian besar melakukan kegiatan membersihkan lingkungan setiap hari (64\%), sebagian besar responden menguras kurang dari satu minggu atau satu kali seminggu(55\%). Sebagian besar responden menutup rapat tempat penampungan air $(60 \%)$. Gerakan 3M tidak sekedar melakukan kegiatan menutup, mengubur dan menguras, tetapi yang juga perlu diperhatikan adalah cara membersihkan tempat penampungan air. Itu berarti tidak hanya mengganti air, tetapi juga menyikat dan membersihkan dinding penampungan air karena tanpa itu, telur Ae.aegypti akan tetap melekat dan dapat melanjutkan siklus hidupnya. Dinding tempat penampungan air yang kasar dapat menyerap air dan gelap merupakan tempat bertelur yang sangat disukai nyamuk Ae.aegypti. Selain itu, telur dapat bertahan hidup sampai waktu enam bulan. ${ }^{8}$ Oleh sebab itu, kegiatan 3M sebaiknya dilakukan secara teratur paling tidak seminggu sekali. Penelitian ini juga menemukan bahwa sebagian besar responden $(69 \%)$ mempunyai kebiasaan menggantung pakaian. Hasil tersebut sesuai dengan temuan penelitian sebelumnya, bahwa peran serta masyarakat memegang peranan penting dalam menurunkan kepadatan vektor di Jakarta Timur yang ditunjukkan oleh penurunan container index dari $12 \%$ menjadi $6 \%$.

\section{Kesimpulan}

Secara keseluruhan, penelitian ini menemukan tingkat partisipasi masyarakat Kelurahan Bonto Makkio dan Kelurahan Gunung Sari Kecamatan Rappocini, Kota Makasar rendah. Masyarakat yang membersihkan lingkungan setiap hari (64\%), kebiasaan menguras tempat penampungan air kurang atau satu kali seminggu $(64 \%)$, kebiasaan menutup tempat penampungan air sebagian $(60 \%)$ dan kebiasaan menggantung pakaian $(69 \%)$. Penelitian ini menemukan nilai density figure House Indeks (3), Container Indeks (3) dan Density Figure (4) yang tidak berpotensi untuk terjadi penularan penyakit Demam Berdarah Dangue.

\section{Saran}

Berdasarkan kesimpulan dapat diambil rekomendasi 
kebijakan sebagai berikut: kebijakan penanggulangan Demam Berdarah Dengue perlu mendapat payung hukum berupa peraturan daerah yang mana peraturan daerah ini memberikan denda administrasi bagi masyarakat yang tidak melakukan pemberantasan breeding place dari Aedes aegypti. Membentuk kader pemantau jentik yang berbasis keluarga yang diperankan oleh Ibu Rumah Tangga (ibu pemantau jentik/Bu-Mantik) melalui pelatihan secara bertahap yang melibatkan unsur PKK atau organisasi setingkat kelurahan. (Saran yang disampaikan ini belum pernah disinggung dalam pembahasan).

\section{Daftar Pustaka}

1. WHO. Climate change and human health - risk \& responses [edisi 2002, diakses tanggal 21 Mei 2006]. Diunduh dari: http://www.cdc.gov/ncidod/dvbid/dengue.

2. Departemen Kesehatan RI. Menuju desa bebas demam berdarah dengue. Jakarta: Dirjen PPM dan PLP; 2002.
3. Dinas Kesehatan Kota Makassar. Profil kesehatan kota Makassar. Makasar: Dinas Kesehatan Kota Makassar; 2006.

4. Dinas Tata Ruang dan Pemukiman Propinsi Sulawesi Selatan. Identifikasi kawasan kumuh Sulawesi Selatan, proyek peningkatan kualitas lingkungan. 2002.

5. Wahiduddin. Analisis faktor yang berhubungan dengan kejadian demam berdarah dengue (DBD) di wilayah puskesmas Kassi-Kassi kota Makassar [tesis]. Makasar: Universitas Hasanuddin; 2003.

6. Ahmad, Hamsir. Analisis efektifitas fogging fokus dan diskusi kelompok terarah menutup, menguras dan mengubur (KDT $3 \mathrm{M}$ ) terhadap penurunan densitas jentik nyamuk aedes aegypti di wilayah kumuh endemis kota Makassar [tesis]. Makasar: Universitas Hasanuddin; 2007.

7. Widyana. Faktor-faktor risiko yang mempengaruhi kejadian DBD di kabupaten Bantul. Jurnal Epidemiologi. 1998; 1.

8. Cussi, Lestari. Upaya mengatasi faktor-faktor penghambat pemberantasan demam berdarah dengue. Majalah Kedokteran Indonesia. 2005; 55 (11). 